\title{
A cellular and proteomic approach to assess proteins extracted from cryopreserved human amnion in the cultivation of corneal stromal keratocytes for stromal cell therapy
}

\author{
Beau J. Fenner ${ }^{1,2+}$, Nur Zahirah B. M. Yusoff ${ }^{1 \dagger}$, Matthias Fuest ${ }^{1,3}$, Lei Zhou ${ }^{4,5}$, Francisco Bandeira ${ }^{1,6}$,
} Howard Y. Cajucom-Uy', H. K. $\operatorname{Tan}^{8}$, Jodhbir S. Mehta ${ }^{1,2,4^{*}}$ and Gary H. F. Yam ${ }^{1,4^{*}}$ (D)

\begin{abstract}
Background: Human corneal stromal keratocytes propagated in culture media supplemented with human amnion extract (AME) can correct early corneal haze in an animal model. Clinical application of cultivated keratocytes is limited by infectious disease screening before amnion products can be used in humans. It remains unclear if AME from cryopreserved versus fresh human amnion can support human keratocyte propagation, and which components of the extract promote keratocyte growth.

Methods: Three placentas were collected for the preparation of fresh and cryopreserved amnion tissues followed by homogenization and protein extraction. AME protein profiles were studied using isobaric tagging for relative and absolute quantitation (iTRAQ) proteomics. Enriched gene ontology (GO) terms and functional classes were identified. Primary human keratocytes from 4 donor corneas were cultured in media supplemented with fresh AME (F-AME) or cryopreserved AME (C-AME). Cell viability, proliferation and keratocyte marker expression were examined by confocal immunofluorescence and flow cytometry.

Results: AME proteomics revealed 1385 proteins with similar expression levels (between 0.5 - and 2-fold) between Fand C-AME, while 286 proteins were reduced (less than 0.5-fold) in C-AME. Enriched GO term and biological pathway analysis showed that those proteins with comparable expression between F-AME and C-AME were involved in cell metabolism, epithelial-mesenchymal transition, focal adhesion, cell-extracellular matrix interaction, cell stress regulation and complement cascades. Human corneal stromal keratocytes cultured with F-AME or C-AME showed similar morphology and viability, while cell proliferation was mildly suppressed with C-AME $(P>0.05)$. Expression of aldehyde dehydrogenase 3A1 (ALDH3A1) and CD34 was similar in both cultures.
\end{abstract}

Conclusion: AME from cryopreserved amnion had limited influence on keratocyte culture. It is feasible to use protein extract from cryopreserved amnion to propagate human keratocytes for potential translational applications.

Keywords: Amnion extract, Proteomics, Corneal stromal keratocytes, Marker expression

\footnotetext{
* Correspondence: jodmehta@gmail.com; gary.yam@gmail.com

${ }^{+}$Beau J. Fenner and Nur Zahirah B. M. Yusoff contributed equally to this

work.

${ }^{1}$ Tissue Engineering and Stem Cell Group, Singapore Eye Research Institute,

20 College Road, The Academia, Discovery Tower Level 6, Singapore 169856,

Singapore

Full list of author information is available at the end of the article
}

(c) The Author(s). 2019 Open Access This article is distributed under the terms of the Creative Commons Attribution 4.0 International License (http://creativecommons.org/licenses/by/4.0/), which permits unrestricted use, distribution, and reproduction in any medium, provided you give appropriate credit to the original author(s) and the source, provide a link to the Creative Commons license, and indicate if changes were made. The Creative Commons Public Domain Dedication waiver (http://creativecommons.org/publicdomain/zero/1.0/) applies to the data made available in this article, unless otherwise stated. 


\section{Background}

A transparent cornea, which allows uninterrupted passage of light to the retina, is the basis for normal vision. The corneal stroma, which makes up about $90 \%$ of the corneal volume, consists of highly organized extracellular matrix (ECM) interspersed with corneal stromal keratocytes (CSKs), contributing to the physical strength and optical properties of the cornea [1]. Corneal opacification, due to scarring and opacities inside the corneal stroma, is a significant cause of global blindness $[2,3]$. This reduces and distorts light passage, leading to decreased vision or visual loss. In most situations, surgical removal (corneal transplantation) is commonly used to restore the vision of patients with opacification, such as in keratoconus, post-infection scarring. Recent advances in eye banking and surgical techniques (lamellar keratoplasty), have offered practical advantages over penetrating keratoplasty (such as shorter surgery time, faster recovery and less rejection risk), however, the treatment approach is still limited by the global shortage of donor corneal tissue, long-term graft survival, immune response and the need of surgical expertise [4-6]. Hence, the development of robust strategies, like cell-based therapies, is desirable to restore stromal functions and corneal transparency for patients with corneal opacities [7-11].

Our group has previously reported on the use of intrastromal injection of CSKs to arrest corneal haze development and restore corneal clarity in a rat model of early corneal opacities [12]. Stromal cell-based strategies require ex vivo propagation of CSKs. However, CSKs obtained from donor corneas are challenging to propagate under standard culture conditions [13, 14]. Using serum and growth factor-supplemented media, CSKs rapidly differentiate into stromal fibroblasts (SFs) and lose specific keratocyte features, including the expression of keratan sulphate proteoglycans (lumican, keratocan), which regulates collagen fibril alignment and spacing, and stromal crystallins (transketolase, aldehyde dehydrogenase ALDH1A1 and 3A1) for transparency and refractivity $[15,16]$. This irreversible change has created obstacles to the application of cultured stromal cells as a medically useful corneal stromal replacement. SF injection to normal rodent corneas deposited fibrotic ECM proteins to increase light scattering, resulting in haze development [12, 17]. The elevated metalloproteinase levels released by fibroblasts also triggered neovascularization [12]. Hence, the use of correct stromal cell type (i.e., CSKs) is crucial for corneal stromal therapy.

Our group has described the ex vivo propagation of human CSKs using culture medium supplemented with human amnion extract (AME), Rho-associated coiled-coil containing protein kinase (ROCK) inhibitor (Y27632) and insulin-like growth factor 1 (IGF1) (known as ERI supplement) [18]. In the presence of low serum levels, CSKs slowly propagated as "activated keratocytes" without transiting into SFs. After serum withdrawal, they reexpressed keratocyte markers, including lumican, keratocan, ALDH1A1, 3A1, collagen 8A2, CHST6 and B3GNT7. This protocol requires AME as an essential component to suppress transforming growth factor $\beta$ (TGF $\beta$ )-mediated fibroblast transition [18].

Human amnion is known to exert anti-inflammatory, anti-microbial and anti-scarring effects, secrete immunosuppressive factors and promote epithelial wound healing [19-27]. Amnion stroma has been shown to contain growth factors and bioactive substances in regulating TGF $\beta$ signalling that support CSK propagation [14, 18, 28, 29]. It remains unknown whether amnion cryo-storage interferes with its ability to promote CSK growth in culture. In this work, we have examined the effects of cryopreservation on AME for human CSK culture and the changes of AME proteomics after cryopreservation.

\section{Methods}

\section{Human amniotic membrane collection}

Human placentas $(n=3$, foetuses of either gender) were collected after elective caesarean section with written consent from mothers (age $<40$ years old), using a protocol approved by our institutional review board (2015/ 2607, SingHealth, Singapore). After multiple rinses with sterile saline to remove blood traces, the amnion was isolated from the chorion. The amnion portion proximal to the placenta was collected and trimmed into approximately $1 \mathrm{~cm}^{2}$ segments. Half of amnion pieces were processed immediately for fresh amnion extract (F-AME), and the remainder were cryopreserved in Dulbecco's modified Eagle medium (DMEM, Invitrogen, Carlsbad, CA, US) containing 50\% glycerol (Sigma-Aldrich, St Louis, MI, US) at $-80{ }^{\circ} \mathrm{C}$ for a week and processed for cryopreserved amnion extract (C-AME).

\section{AME preparation}

Amnion pieces were washed with sterile phosphate buffered saline (PBS, $0.1 \mathrm{M}$, Invitrogen), drip-dried, weighed, and ground under the air phase of liquid nitrogen. The homogenate was agitated at 100 r.p.m. with sterile PBS $\left(5 \mathrm{ml} / \mathrm{g}\right.$ tissue) for $48 \mathrm{~h}$ at $4{ }^{\circ} \mathrm{C}$. The suspension was passed through a $70 \mu \mathrm{m}$ filter (Falcon, Corning, NY, US) and centrifuged at $3000 \mathrm{~g}$ for $20 \mathrm{~min}$. The supernatant was further spun at $48,000 \mathrm{~g}$ for $20 \mathrm{~min}$ at $4{ }^{\circ} \mathrm{C}$. The clear liquid was collected, aliquoted and stored at $-80^{\circ} \mathrm{C}$. An aliquot of each sample was used for protein quantification using Protein DC assay (Bio-Rad, Hercules, CA, US), expression of human tissue inhibitor of metalloproteinase 1 (TIMP1 enzyme-linked immunosorbent assay (ELISA); Invitrogen) and protein mass profiling by sodium dodecylsulfate-polyacrylamide gel electrophoresis (SDSPAGE). Samples were denatured in buffer containing 
$50 \mathrm{mM}$ Tris- $\mathrm{HCl}, 2 \%$ SDS, $1 \% \beta$-mercaptoethanol, 5\% glycerol and bromophenol blue (all chemicals procured from Sigma-Aldrich) and resolved using gradient SDS-PAGE (4-20\% gradient; Bio-Rad). Gels were stained with Coomassie-blue G-250 and visualized under bright field imaging (GelDoc, Bio-Rad).

\section{Quantitative AME protein analysis}

Protein samples were quantitatively analysed using isobaric tagging for relative and absolute quantitation iTRAQ combined with one-dimensional nano liquid chromatography (LC)-nano-electrospray ionization (ESI)-mass spectrometry (MS)/MS. Analytical runs were performed in triplicates. After denaturation in $50 \mathrm{mM}$ ammonium bicarbonate solution, 2\% SDS and Tris (2-carboxyethyl) phosphine (TCEP) (reagents in iTRAQ kit, AB Sciex, Framingham, MA, US) for $1 \mathrm{~h}$ at $60^{\circ} \mathrm{C}$, protein samples were transferred to a $30 \mathrm{kDa}$ cut-off membrane cartridge (Expedeon, San Diego, CA, US) for concentration using 75\% urea solution. They were alkylated with methylmethane thiosulfonate (MMTS; AB Sciex), washed with $75 \%$ urea and $50 \mathrm{mM}$ ammonium bicarbonate solution prior to trypsin digestion, which was performed under a substrate: enzyme ratio of 1:25 for overnight. After elution with ammonium bicarbonate and sodium chloride, proteins were labelled with iTRAQ reagents for $3 \mathrm{~h}$, dried and desalted with ultramicrospin columns (Nest Group, Southboro, MA, US).

Labelled proteins were analysed using one-dimensional nano LC-MS/MS (Dionex Ultimate 3000 Nano LC system; ThermoFisher Sci, Sunnyvale, CA, US), coupled with AB Sciex TripleTOF 5600 system (AB Sciex). A Dionex Acclaim PepMap RSLC C18 packed column (ThermoFisher Sci) was connected to a spray tip (New Objective, Woburn, MA, US). They were loaded to a Dionex Acclaim PepMap 100 C18 column (ThermoFisher Sci) and washed with acetonitrile $(2 / 98, \mathrm{vol} / \mathrm{vol})$, acetonitrile $(\mathrm{ACN}) /$ water with $0.1 \%$ formic acid, followed by a step linear gradient of mobile phase B $(2 / 98 \mathrm{vol} / \mathrm{vol}$ of water/ACN with $0.1 \%$ formic acid) starting from 7 to $24 \%$ for $57 \mathrm{~min}$, to $24-40 \%$ for $27 \mathrm{~min}$, to $40-60 \%$ for $7 \mathrm{~min}$, and $60-95 \%$ for $1 \mathrm{~min}$, at a flow rate of $300 \mathrm{nl} / \mathrm{min}$. The TripleTOF 5600-MS was setup as: ionspray voltage floating $=2400 \mathrm{~V}$, curtain gas $=$ 30 , ion source gas $1=12$, interface heater temperature $=$ $125^{\circ} \mathrm{C}$, declustering potential $=100 \mathrm{~V}$. Data were acquired using information-dependent acquisition (IDA) mode with Analyst TF1.5 (AB Sciex). TOF-MS scan parameters were: $0.25 \mathrm{~s}$ accumulation time at the mass range of 350 to $\sim 1250 \mathrm{Da}$ followed by product ion scan of $0.05 \mathrm{~s}$ accumulation time at the mass range of 100 to $1500 \mathrm{Da}$. Switching criteria were set to ions greater than $\mathrm{m} / \mathrm{z}=350$ and smaller than $\mathrm{m} / \mathrm{z}=1250$ with charge state of 2 to 5 , and an abundance threshold of greater than 120 counts/s. Former target ions were excluded for $12 \mathrm{~s}$ and former ions were excluded after one repeat. Maximum number of candidate ions per cycle was 30 spectra. IDA advanced "rolling collision energy (CE)" and "adjust CE when using iTRAQ reagent" were required.

\section{AME proteomic data analysis}

Data were processed and searched against the IPI Human v3.77 database (115,194 proteins) using ProteinPilot 4.1 (AB Sciex). For protein identification, the confidence level was set at $95 \%$ and false discovery rate (FDR) less than $1 \%$. Reverse search strategy was used to calculate FDR. For relative quantification, ProteinPilot with the Pro Group algorithm was used to calculate the reporter ions' peak areas. Automated bias correction was applied to eliminate possible pipetting error during sample preparation.

\section{Differential protein expression, pathway and statistical analyses}

Each sample was analysed in duplicates by iTRAQ, and only data points that were within the $30 \%$ coefficient of variance value were used for analysis with outlier exclusion. Expression ratios of protein in C-AME over FAME were calculated. Cut-off values of $\geq 2$-fold and $\leq$ 0.5 -fold between samples were used. Proteins with changes less than these were considered unaffected. Only proteins with consistent changes in all amnion storage pairs were analysed.

\section{Gene ontology (GO) and functional class enrichment analyses}

GO terms were determined using GO Resource and PANTHER [30]. Overrepresentation of functional classes was determined with the Database for Annotation, Visualization and Integrated Discovery (DAVID) Bioinformatics Resource v6.8, with a Benjamini statistic cut-off of 0.05 being used to determine statistical significance of overrepresented classes.

\section{Donor human corneas and primary keratocyte culture}

Clinical grade cadaveric corneal tissues $(n=4)$ were procured from Lions Eye Institute for Transplant and Research Inc. (Tampa, FL, US) following institutional review board approval in accordance with approved guidelines. Consent was taken at the time of retrieval by the next of kin, for use in research. Mean donor age was $53.7 \pm 7.2$ years old and the male-to-female ratio was 1:1. They were preserved in Optisol-GS (Bausch \& Lomb Surgical, Irvine, CA, US) and transported at $4{ }^{\circ} \mathrm{C}$ to the culture facility. The central button $(8 \mathrm{~mm}$ diameter) was trephined and treated with dispase II $(20 \mathrm{mg} / \mathrm{ml}$; Roche, Basal, Switzerland) followed by gentle scrapping to completely remove corneal epithelium and endothelium. The stromal tissue was digested with collagenase I ( $1 \mathrm{mg} / \mathrm{ml}$; Worthington, Lakewood, NJ, US) for $6-8 \mathrm{~h}$ at $37^{\circ} \mathrm{C}$. Single cells were washed and plated on 
collagen I-coated culture surface using CSK propagation medium added with ERI supplements and serum (SERI), comprised of DMEM/F12 with L-glutamate (2 $\mathrm{mM})$, HEPES (20 mM), sodium pyruvate ( $1 \mathrm{mM}$, Sigma), insulin-transferrin-selenate (1\%, Invitrogen), antibioticsantimycotic (penicillin S, streptomycin sulphate and amphotericin B, Invitrogen), and supplemented with Lascorbate 2-phosphate ( $1 \mathrm{mM}$, Sigma), Y27632 (1 $\mu \mathrm{M}$; Millipore), insulin-like growth factor $1(10 \mathrm{ng} / \mathrm{ml}$; Invitrogen) and $0.5 \%$ fetal bovine serum (FBS, Gibco) [18]. The media were added with either F-AME or C-AME $(5 \mu \mathrm{g}$ protein $/ \mathrm{ml}$ ). Fresh media was replenished every 3 days. The cultures were sub-passaged when confluence was about $70 \%$. At passage 4, the cultures were switched to serum-free ERI condition for 7 days. During culture, the cells were cultivated continuously with fresh or cryopreserved AME.

\section{Cell viability - Calcein AM assay}

At day 7 of serum-free ERI culture, calcein AM and ethidium homodimer-1 (EthD-1) were added to incubate for $45 \mathrm{~min}$ following the Live/Dead Viability/Cytotoxicity kit protocols (Life Technologies). After washes, the samples were mounted in Fluoroshield (Santa Cruz Biotech, Santa Cruz, CA, US) and viewed with a 10x objective under fluorescence microscopy (AxioImager Z1, Carl Zeiss, Oberkochen, Germany). In a minimum of 6 random fields, the number of live (green fluorescence) and dead cells (red fluorescence) was quantified and the percentage of cell viability was calculated and represented as mean \pm SD. Experiments were performed in triplicates.

\section{Cell proliferation - click-iT EdU assay}

At day 5 of serum-free ERI culture, EdU $(10 \mu \mathrm{M}$, Life Technologies) was added and incubated for $48 \mathrm{~h}$. Cells were fixed with $4 \%$ paraformaldehyde (Sigma), permeabilized with $0.5 \%$ Triton X-100 (Tx, Sigma) and blocked with 3\% bovine serum albumin (BSA, Sigma). Click-iT reaction solution (Life Technologies) was added to cells for $30 \mathrm{~min}$. After washes, samples were mounted in DAPI-added Fluoroshield and viewed under fluorescence microscopy with a $10 x$ objective. In a minimum of 6 random fields, the cell proliferation indices were calculated as the percentages of EdU-labelled nuclei and presented as mean \pm SD. Experiments were performed in triplicates.

\section{Flow cytometry}

After serum-free ERI culture, CSKs were fixed with 2\% paraformaldehyde (Sigma), permeabilized and blocked by $1 \% \mathrm{Tx}, 2 \% \mathrm{BSA}$ and $2 \%$ normal goat serum (NGS, Invitrogen). Cell samples were incubated with rabbit anti-human ALDH3A1 antibody (Proteintech, Rosemont, IL, US), APC-conjugated CD34 antibody (ThermoFisher) or isotype-specific IgG (BD Biosciences, Singapore), followed by FITC-conjugated IgG secondary antibody and propidium iodide. Results were analysed by FACSVerse (BD Biosciences) using a minimum of 10,000 events per experiment. Percentages of positively labelled cells were calculated using FACSuite (BD Biosciences, Singapore).

\section{Immunofluorescence, ultra-wide field confocal microscopy, z-series reconstruction, cell quantification} Cells on coverslips were fixed with $2 \%$ paraformaldehyde, quenched with ice-cold $50 \mathrm{mM}$ ammonium chloride (Sigma-Aldrich) and permeabilized with $0.15 \%$ saponin (Sigma-Aldrich). After blocking with 1\% BSA and 2\% NGS, they were incubated with polyclonal antibodies against ALDH3A1 and CD34 (Millipore), respectively, for $2 \mathrm{~h}$ at room temperature. After washes, the labelling signal was revealed by secondary antibody conjugated with AlexaFluor 488 or AlexaFluor 594 (Jackson InnumoResearch Lab, West Grove, PA, US). Samples were mounted in DAPI-added Fluoroshield and viewed under ultra-wide field spinning disk laser confocal microscopy (CSU W1, Nikon) using the "scan large image" mode (NIS Elements, v.4.40). Scan boundaries were marked at $10 \mathrm{x}$ magnification with the pixel size set at $0.64 \times 0.64 \mu \mathrm{m}$ and serial z-stacks at $2 \mu \mathrm{m}$. Mosaic images were acquired and automatically stitched with $\mathrm{XY}$ overlap at $15 \%$. Under a maximum intensity projection function, all $\mathrm{z}$-stacks were merged into a single $2 \mathrm{D}$ image. Each culture was performed on 5 coverslips. On each coverslip, at least 5 random fields of $500 \times 500 \mu \mathrm{m}$ were selected for quantifying the immunostained cells and cell percentages against total number of cells (DAPI-labelled) were calculated. Overall percentage was presented as mean $\pm \mathrm{SD}$.

\section{Statistical analysis}

Paired Mann-Whitney U (Wilcoxon rank-sum) tests were used to compare cell viability, proliferation rates and percentages of cells expressing keratocyte markers between F-AME and C-AME-supplemented cultures. Results were described as mean \pm SD. Statistics were performed using SPSS 20.0 (SPSS, Chicago, IL, US) and Prism 8.0 (GraphPad, San Diego, CA, US). $P<0.05$ was considered statistically significant.

\section{Results}

Proteomic profiles of C-AME versus F-AME

Soluble AME from 3 donor placentas were prepared with fresh amnion tissue or following cryopreservation at $-80^{\circ} \mathrm{C}$ for a week. Inspection of gel electrophoresis results indicated that the process of cryopreservation altered the relative abundances of some proteins, most markedly a relative reduction of proteins with molecular mass below $40 \mathrm{kDa}$ in AME from cryopreserved amnion (Fig. 1a). The quality of F-AME prepared from each 

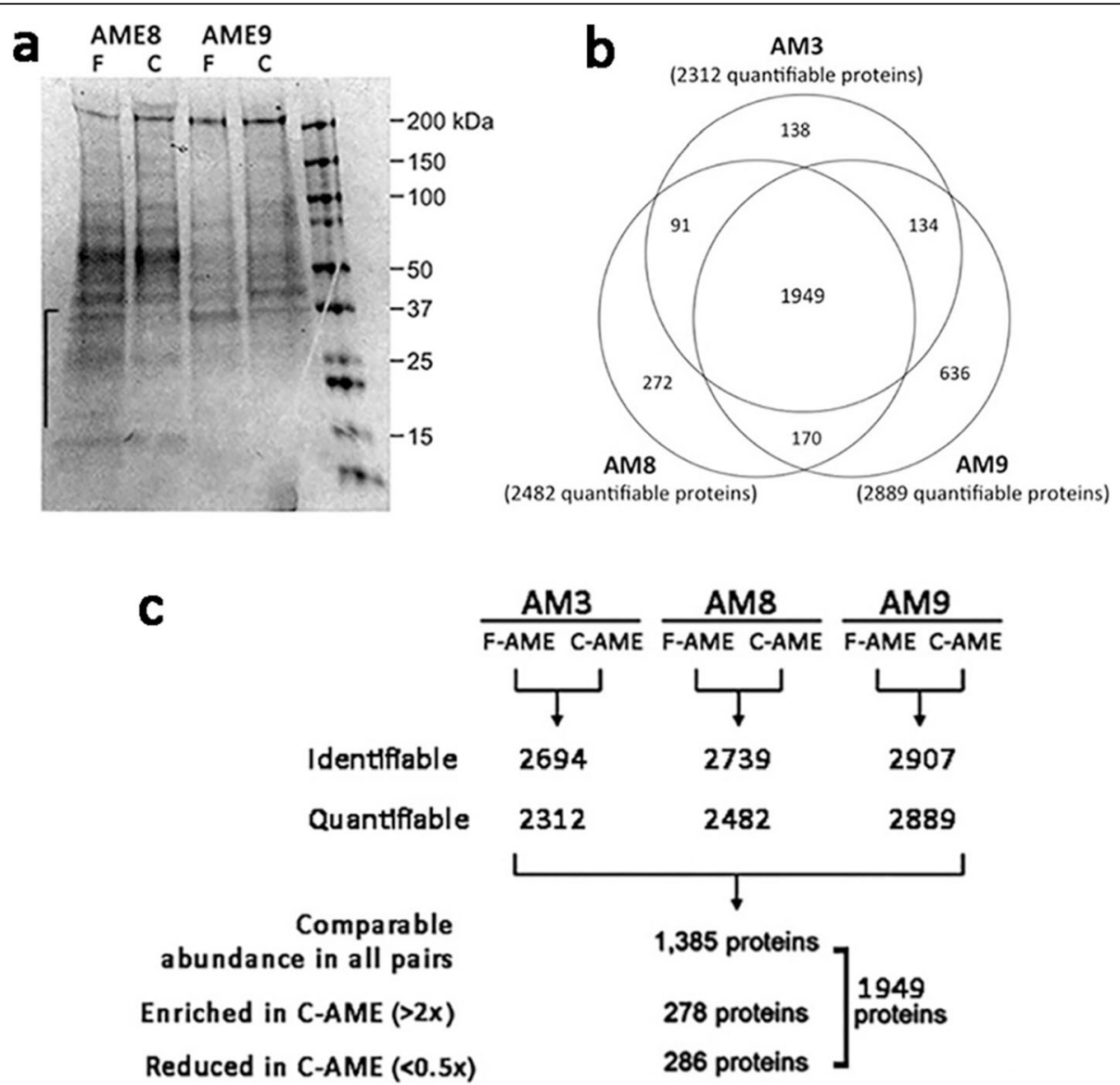

2312

2482

2889

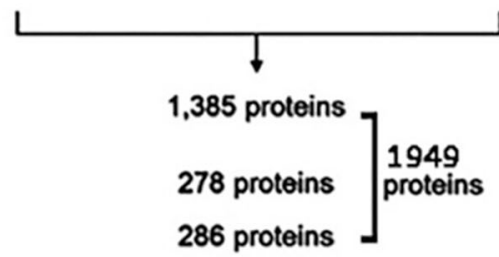

Fig. 1 Soluble amnion extract protein profiles. a Denaturing gel electrophoresis of amnion extract proteins from fresh and cryopreserved human amnion (F-AME and C-AME). Twenty micrograms of protein prepared from fresh and frozen amnion of two donor tissues, AME8 and AME94 was subjected to 4-20\% SDS-PAGE. Major protein bands distribution was revealed after Coomassie brilliant-259 blue staining. Proteins below molecular mass $40 \mathrm{kDa}$ were relatively depleted in C-AME samples. The right-most lane is molecular size ladder. b Pie chart representation of quantifiable protein distribution from 3 amnion samples. c Experimental approach for iTRAQ proteomic profiling of F-AME and C-AME obtained from 3 different amnion samples (AM3, AM8, AM9). The amount of identifiable and quantifiable proteins is listed. The number of proteins comparatively present $(<2$ and $>0.5$ fold), enriched ( $>2$ folds) and reduced $(<0.5$ fold $)$ in all amnion samples are indicated

amnion sample was comparable based on TIMP1 ELISA (AM3: $47 \mathrm{ng} / \mathrm{mg}$ protein; AM8: $41 \mathrm{ng} / \mathrm{mg}$ protein; AM9; $64 \mathrm{ng} / \mathrm{mg}$ protein).

Proteomic profiling of F-AME and C-AME yielded an average of 2194 identifiable proteins and 1812 quantifiable proteins in AM3 samples; 2739 identifiable proteins and 1482 quantifiable proteins in AM8 samples; and 2907 identifiable proteins and 2889 quantifiable proteins in AM9 samples (Fig. 1b-c). A comparison of quantifiable proteins was performed by identifying proteins that were enriched or reduced between C-AME and F-AME, yielding 278 discrete enriched proteins ( $>2$ folds) and 286 reduced proteins $(<0.5$ fold $)$ in C-AME. The remaining 1385 proteins were considered unchanged (between 0.5 - and 2-fold) between F- and C-AME (Fig. 1c). GO analysis revealed a similar distribution of ontology classes among AME proteins in the comparable, enriched and reduced populations (Fig. 2a-c). Proteins with comparable expression in both F-
AME and C-AME were predominantly associated with cellular and metabolic processes in the category of biological processes; catalytic activity and binding in molecular functions; and organelles and protein containing complex in cellular components. Similar trends were seen for enriched and reduced proteins in C-AME compared to F-AME. Some overlaps were found in the over-represented functional classes in C-AME versus F-AME (Fig. 3). Among proteins with unchanged expression levels, they were involved in cell-cell adhesion, translational initiation, and protein and RNA metabolism. Cell-cell adhesion proteins were similarly over-represented among the enriched and reduced proteins in C-AME proteomes.

\section{AME proteins preserved after AM cryopreservation}

Supplementation of culture media with F-AME or CAME had no significant effect on human CSK viability, proliferation and marker expression. This indicated that 


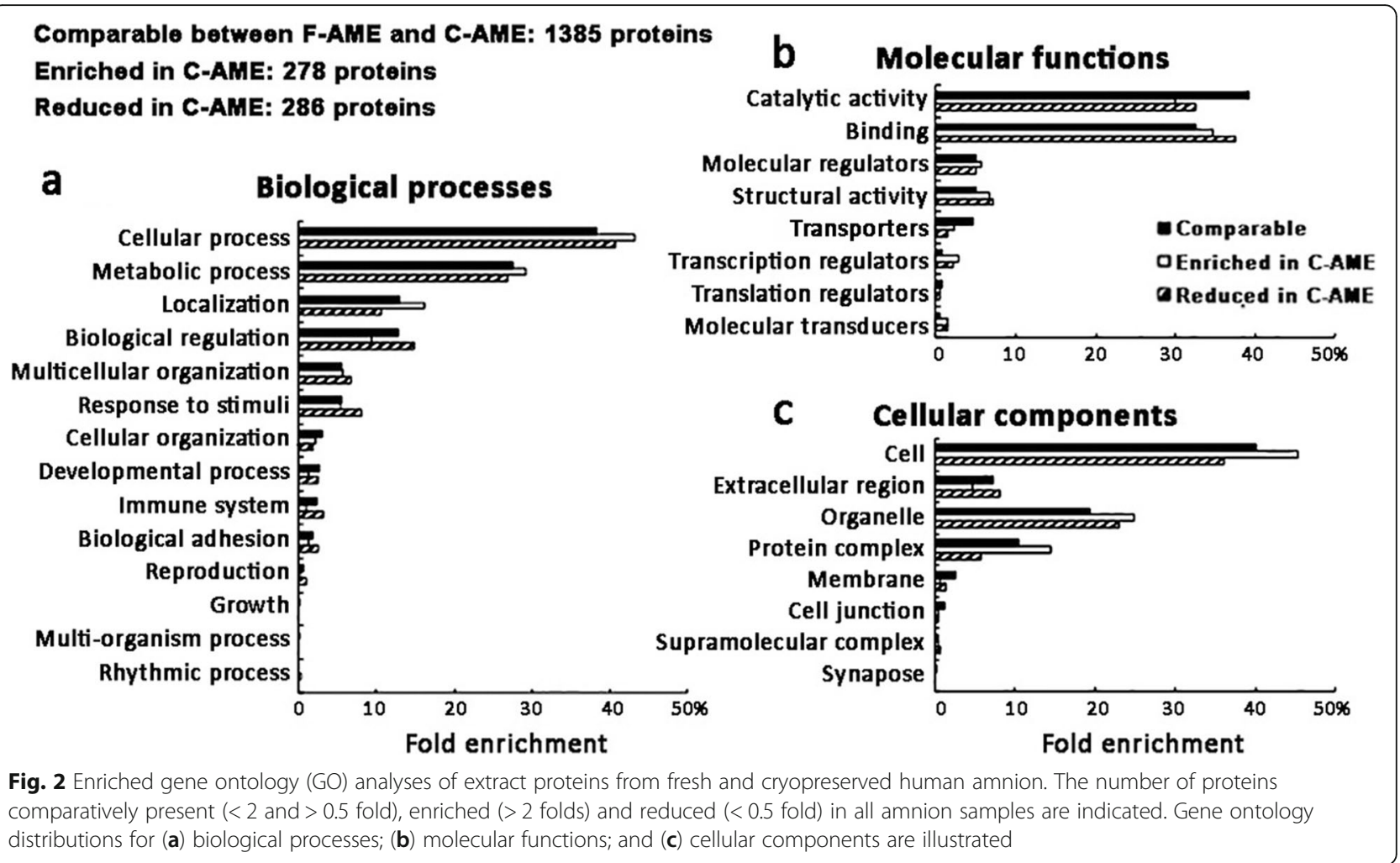

proteins with comparable expression levels in F-AME and C-AME ( $n=1385$ proteins) would be important to CSK growth in culture (Supplemental information). Using DAVID functional annotation, the enriched GO terms predicted for these proteins were significantly associated to Fc-epsilon receptor signalling pathway $(P<$ 0.001, Benjamini test; enrichment score EnS:6.55), NIK/
NF-kappaB signalling $(P<0.001 ;$ EnS:6.55), regulation of mRNA stability $(P<0.001$; EnS:6.55), protein polyubiquitination $(P<0.001$; EnS:3.87), and cell-cell adhesion $(P=0.02$; EnS:3.63) (Table 1$)$. The significant Kyoto encyclopedia of genes and genomes (KEGG) pathways were proteasome $(P<0.01$; EnS:6.55), complement and coagulation cascades $(P=0.043$; EnS:3.43).

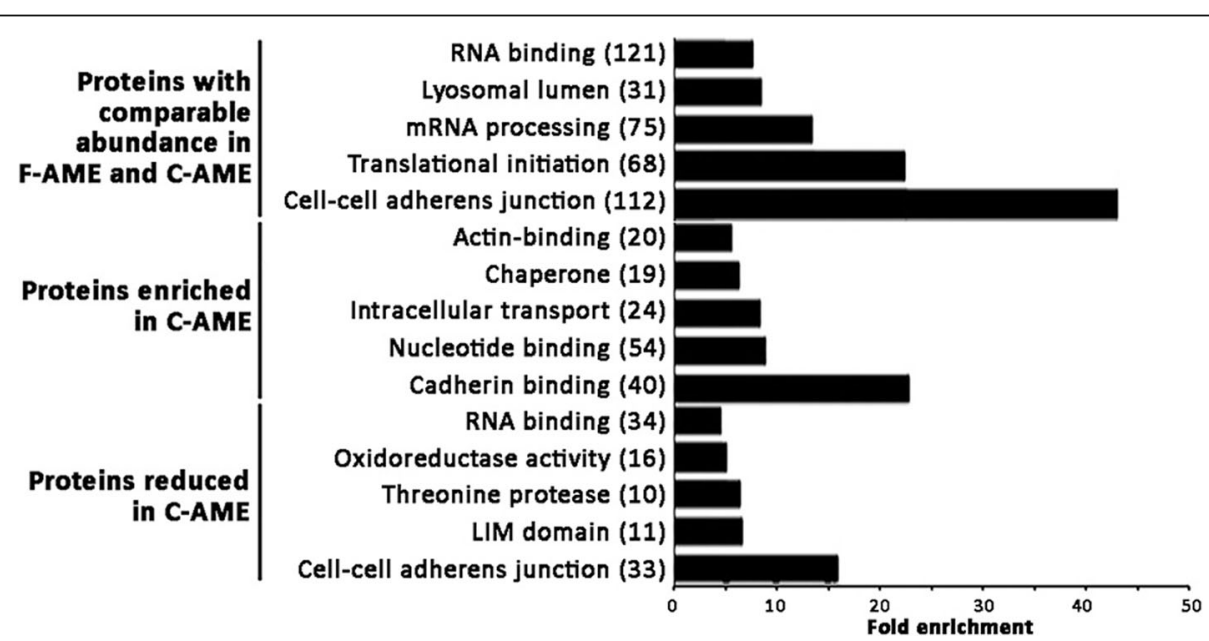

Fig. 3 Enrichment analysis of functional protein groups identified by iTRAQ proteomics using amnion extracts derived from fresh or cryopreserved human amnion. Enriched GO analyses were performed and the top 10 enriched functional classes from C-AME proteins that were either of comparable abundance, enriched or reduced relative to F-AME were plotted. The number of discrete proteins for each functional class is shown in parenthesis beside the functional class names. Fold enrichment for each functional class relative to the prevalence of that functional class in the total human proteome is listed on X-axis 
Table 1 Enriched Gene Ontology terms and KEGG pathways identified for proteins similarly expressed in F-AME and C-AME (between 0.5- and 2-fold) of 3 donor amnion samples

\begin{tabular}{|c|c|c|c|c|}
\hline & Enrichment scores & Biological pathways & Proteins (UniProt Accession no.) & $p$ \\
\hline \multicolumn{5}{|c|}{ (A) Enriched GO terms (DAVID) } \\
\hline 1 & 6.55 & GO:0038095 Fc-epsilon receptor signalling pathway & $\begin{array}{l}\text { P20618, P25789, P25786, P28070, P01700, O14818, } \\
\text { P63208, P60900, P49721, P49720, P63098, P0DOY3 }\end{array}$ & $2.8 \mathrm{E}-6^{*}$ \\
\hline 2 & 6.55 & GO:0038061 NIK/NF-kappaB signalling & $\begin{array}{l}\text { P20618, P25789, P25786, P28070, O14818, P63208, } \\
\text { P60900, P49721, P49720 }\end{array}$ & $2.3 \mathrm{E}-6^{*}$ \\
\hline 3 & 6.55 & GO:0043488 regulation of mRNA stability & $\begin{array}{l}\text { P20618, P27695, P25789, P25786, P28070, O14818, } \\
\text { Q92945, P60900, P49721, P49720 }\end{array}$ & $1.9 \mathrm{E}-6^{*}$ \\
\hline 4 & 3.87 & GO:0000209 protein polyubiquitination & $\begin{array}{l}\text { P20618, P25789, P25786, P28070, O14818, P63208, } \\
\text { P60900, P49721, P49720 }\end{array}$ & $4.6 \mathrm{E}-04^{*}$ \\
\hline 5 & 3.63 & GO:0098609 cell-cell adhesion & P30041, O60437, P62820, P46109, Q92817, Q15907, P43487 & $0.02^{*}$ \\
\hline 6 & 3.12 & GO:0000398 mRNA splicing, via spliceosome & P52597, Q08170, P22626, P14866, Q16629, Q86U42 & 0.19 \\
\hline \multicolumn{5}{|c|}{ (B) KEGG pathways (DAVID) } \\
\hline 1 & 6.55 & hsa03050: Proteasome & $\begin{array}{l}\text { P20618, P25789, P25786, P28070, O14818, P60900, } \\
\text { P49721, P49720 }\end{array}$ & $1 E-5^{*}$ \\
\hline 2 & 3.43 & hsa04610: Complement and coagulation cascades & P01008, P02746, P01009, P00488 & $0.043^{*}$ \\
\hline 3 & 3.426 & hsa03010: Ribosome & $\begin{array}{l}\text { P42766, P46779, P39019, Q969Q0, P62979, P62899, } \\
\text { P62917, P62266, Q02878, P42677 }\end{array}$ & 0.082 \\
\hline 4 & 3.113 & hsa03040: Spliceosome & $\begin{array}{l}\text { P26368, O14776, P51991, O75533, Q13435, P62312, } \\
\text { O43143, P09012, P08621, Q6P2Q9 }\end{array}$ & 0.072 \\
\hline
\end{tabular}

$G O=$ gene ontology, $K E G G=$ kyoto encyclopedia of genes and genomes, $F-A M E=$ fresh human amnion extract, $C-A M E=c r y o p r e s e r v e d ~ h u m a n$ amnion extract, $D A V I D=$ database for annotation, visualization and integrated discovery

The biological events were ranked using enrichment scores. ${ }^{*}$ Adjusted Benjamini $p<0.05$ represents statistical significance

We selected the top 40 abundant proteins expressed in both F-AME and C-AME and examined their predicted roles in CSK cultivation (Table 2). Identification of specific functional classes was performed using the Wilcoxon pathway enrichment analysis component. Identified proteins that were involved in epithelialmesenchymal transition, focal adhesion, cell-ECM interaction and receptor tyrosine kinase-signalling included serum albumin, filamin $B$, vimentin, tenascin, moesin, collagen 2A1, 1A1, 3A1, 6A3 and 14A1. Cell metabolism and stress response proteins included serum albumin, filamin $B$, spectrin $\alpha$, serotransferrin, prelamin $A / C$, pyruvate kinase, protein disulfide-isomerase $A 3$, heat shock 71 $\mathrm{kDa}$ protein, ezrin, glucose regulated $78 \mathrm{kDa}$ protein, neural $\alpha$-glucosidase $\mathrm{AB}$, moesin and hydropyrimidinaserelated protein 2 .

\section{Downregulated AME proteins after AM cryopreservation}

We identified that 286 proteins were less expressed $(<0.5$-fold $)$ in C-AME, when compared to F-AME. We listed the top 40 downregulated proteins in Table 3, and they included mimecan, annexin A2, A4, cathepsin $\mathrm{B}, \alpha$-enolase, heterogeneous nuclear ribonucleoprotein A3, S100A10, triosephosphate isomerase, heat shock $70 \mathrm{kDa}$ protein $1 \mathrm{~B}$. Using DAVID functional annotation, the enriched GO terms that significantly linked to the downregulated proteins were cell-cell adhesion $(P<0.001$; EnS 15.19), mRNA stability $(P<0.001$;
EnS 6.45), proteolysis $(P<0.001$; EnS 6.45$)$ and glycolytic process $(P=0.026$; EnS 4.23) (Table 4). Two significant KEGG pathways were predicted, which were proteasome $(P<0.01$; EnS 6.45) and biosynthesis of antibiotics $(P=$ 0.014; EnS 4.23).

\section{Keratocyte propagation in culture media supplemented with F-AME or C-AME}

Primary human CSK cultures utilized previously established protocol (see Methods). The cultured cells assumed the characteristic dendritic morphology with cell processes extending to connect with neighbouring cells forming a cellular network (Fig. 4a). Similar cell morphology was observed following culture in media supplemented with either F-AME or C-AME, with good reproducibility among cells harvested from different donor corneas $(n=4)$ and AME pairs $(n=2)$ (Fig. 4a). Cell viability was maintained $>95 \%$ at the 5 th passage under culture in both F-AME and C-AME-supplemented media (Fig. 4b), with no significant difference between extracts from different donor amnion. The rate of cell proliferation, revealed by EdU incorporation, varied from 20 to $80 \%$ depending on primary CSKs from different donors. There was a trend towards lower proliferation in cultures supplemented with CAME, although this was not significantly different than that seen in F-AME supplemented media (Fig. 4c). Expression of keratocyte markers was assessed by immunofluorescence followed by confocal laser microscopy and flow cytometry, 
Table 2 Top 40 proteins with comparable expression ( $<2$ and $>0.5$ fold) between C-AME and F-AME in all amnion samples

\begin{tabular}{|c|c|c|c|c|c|}
\hline No. & UniProt Accession No. & Protein & Protein symbol & Mean Abundance* & Mean fold changes** \\
\hline 1 & P02768 & Serum albumin & ALB & 457 & 0.89 \\
\hline 2 & Q09666 & Neuroblast differentiation AHNAK & AHNAK & 435 & 0.89 \\
\hline 3 & O75369 & Filamin-B & FLNB & 408 & 1.03 \\
\hline 4 & Q99715 & Collagen 12A1 & COL12A1 & 407 & 1.09 \\
\hline 5 & Q8IVF2 & AHNAK Nucleoprotein 2 & AHNAK2 & 242 & 0.82 \\
\hline 6 & P12111 & Collagen 6A3 & COL6A3 & 207 & 1.5 \\
\hline 7 & Q13813 & Spectrin a chain & SPTAN1 & 205 & 1.64 \\
\hline 8 & Q15149 & Plectin & PLEC & 178 & 0.86 \\
\hline 9 & P02452 & Collagen 1A1 & COL1A1 & 173 & 0.63 \\
\hline 10 & P01023 & a2-macroglobulin & $\mathrm{A} 2 \mathrm{M}$ & 172 & 0.8 \\
\hline 11 & P68871 & Haemoglobin subunit $\beta$ & $\mathrm{HBB}$ & 169 & 0.59 \\
\hline 12 & P08670 & Vimentin & VIM & 158 & 1.99 \\
\hline 13 & P02787 & Serotransferrin & TF & 157 & 0.88 \\
\hline 14 & P02545 & Prelamin-A/C & LMNA & 146 & 1.37 \\
\hline 15 & A8K2U0 & a2-macroglobulin-like protein 1 & A2ML1 & 145 & 0.75 \\
\hline 16 & P01024 & Complement C3 & $\mathrm{C} 3$ & 142 & 1.08 \\
\hline 17 & P07355 & Annexin A2 & ANXA2 & 124 & 0.72 \\
\hline 18 & P06396 & Gelsolin & GSN & 122 & 0.91 \\
\hline 19 & P01861 & Immunoglobulin heavy constant ${ }^{4}$ & IGHG4 & 120 & 0.6 \\
\hline 20 & P14618 & Pyruvate kinase & PKM & 113 & 0.99 \\
\hline 21 & P01859 & Immunoglobulin heavy constant $\gamma 2$ & IGHG2 & 109 & 0.56 \\
\hline 22 & P24821 & Tenascin & TNC & 108 & 0.62 \\
\hline 23 & P02461 & Collagen 3A1 & COL3A1 & 108 & 0.99 \\
\hline 24 & P30101 & Protein disulfide-isomerase $\mathrm{A} 3$ & PDIA3 & 98 & 0.56 \\
\hline 25 & P11142 & Heat shock cognate $71 \mathrm{kDa}$ protein & HSPA8 & 94 & 0.89 \\
\hline 26 & P15311 & Ezrin & EZR & 94 & 1.9 \\
\hline 27 & P07585 & Decorin & DCN & 92 & 0.87 \\
\hline 28 & P11021 & 78 kDa glucose-regulated protein & HSPA5 & 92 & 1.08 \\
\hline 29 & P63104 & 14-3-3 protein zeta/delta & YWHAZ & 88 & 0.6 \\
\hline 30 & POCOL5 & Complement C4-B & $\mathrm{C} 4 \mathrm{~B}$ & 83 & 0.88 \\
\hline 31 & POCOL4 & Complement C4-A & $\mathrm{C} 4 \mathrm{~A}$ & 80 & 0.94 \\
\hline 32 & P98160 & $\begin{array}{l}\text { Basement membrane-specific heparan } \\
\text { sulphate proteoglycan core protein }\end{array}$ & HSPG2 & 80 & 1.09 \\
\hline 33 & P05787 & Keratin 8 & KRT8 & 77 & 1.76 \\
\hline 34 & P08603 & Complement factor $\mathrm{H}$ & $\mathrm{CFH}$ & 73 & 0.64 \\
\hline 35 & Q14697 & Neutral a-glucosidase $A B$ & GANAB & 72 & 1.55 \\
\hline 36 & P26038 & Moesin & MSN & 71 & 0.74 \\
\hline 37 & Q16555 & Dihydropyrimidinase-related protein 2 & DPYSL2 & 71 & 1.41 \\
\hline 38 & Q05707 & Collagen 14a1 & COL14A1 & 69 & 1.99 \\
\hline 39 & P13667 & Protein disulfide-isomerase A4 & PDIA4 & 68 & 0.94 \\
\hline 40 & P02788 & Lactotransferrin & LTF & 68 & 0.72 \\
\hline
\end{tabular}

$F-A M E=$ fresh human amnion extract, $C-A M E=$ cryopreserved human amnion extract

*The protein list was ranked by mean abundance. **Mean fold changes from all 3 amnion samples 
Table 3 Top 40 proteins with reduced expression ( $<0.5$ fold) in C-AME, compared to F-AME

\begin{tabular}{|c|c|c|c|c|}
\hline No. & UniProt Accession No. & Protein & Protein symbol & Mean fold changes** \\
\hline 1 & Q8WUF5 & RelA-associated inhibitor & PPP1R13L & 0.010 \\
\hline 2 & P58215 & Lysyl oxidase homolog 3 & LOXL3 & 0.040 \\
\hline 3 & P20774 & Mimecan & OGN & 0.052 \\
\hline 4 & P07355 & Annexin A2 & ANXA2 & 0.057 \\
\hline 5 & O95171 & Sciellin & SCEL & 0.069 \\
\hline 6 & P51991 & Heterogeneous nuclear ribonucleoprotein A3 & HNRNPA3 & 0.081 \\
\hline 7 & P07203 & Glutathione peroxidase 1 & GPX1 & 0.092 \\
\hline 8 & P09429 & High mobility group protein B1 & HMGB1 & 0.098 \\
\hline 9 & 076041 & Nebulette & NEBL & 0.100 \\
\hline 10 & P09525 & Annexin A4 & ANXA4 & 0.111 \\
\hline 11 & P63244 & Receptor of activated protein $C$ kinase 1 & RACK1 & 0.112 \\
\hline 12 & P60174 & Triosephosphate isomerase & TPI1 & 0.113 \\
\hline 13 & Q9UBC9 & Small proline-rich protein 3 & SPRR3 & 0.114 \\
\hline 14 & P23497 & Nuclear autoantigen Sp-100 & SP100 & 0.128 \\
\hline 15 & 015231 & Zinc finger protein 185 & ZNF185 & 0.129 \\
\hline 16 & PODMV9 & Heat shock $70 \mathrm{kDa}$ protein 1B & HSPA1B & 0.130 \\
\hline 17 & Q92541 & RTF1 Homolog, Paf1/RNA Polymerase II Complex Component & RTF1 & 0.131 \\
\hline 18 & Q8NC51 & Plasminogen activator inhibitor 1 RNA-binding protein & SERBP1 & 0.134 \\
\hline 19 & P00338 & L-lactate dehydrogenase A & LDHA & 0.134 \\
\hline 20 & O43768 & Alpha-endosulfine & ENSA & 0.135 \\
\hline 21 & Q9GZT8 & NGG1 Interacting Factor 3 Like 1 & NIF3L1 & 0.136 \\
\hline 22 & P07858 & Cathepsin B & CTSB & 0.137 \\
\hline 23 & P20810 & Calpastatin & CAST & 0.138 \\
\hline 24 & P00558 & Phosphoglycerate kinase 1 & PGK1 & 0.139 \\
\hline 25 & P56211 & cAMP-regulated phosphoprotein 19 & ARPP19 & 0.140 \\
\hline 26 & Q9P258 & Regulator of Chromosome Condensation 2 & $\mathrm{RCC2}$ & 0.147 \\
\hline 27 & P50238 & Cysteine-rich protein 1 & CRIP1 & 0.148 \\
\hline 28 & P60903 & Protein S100-A10 & S100A10 & 0.149 \\
\hline 29 & P62937 & Peptidyl-prolyl cis-trans isomerase A & PPIA & 0.150 \\
\hline 30 & P04075 & Fructose-bisphosphate aldolase A & ALDOA & 0.151 \\
\hline 31 & Q01469 & Fatty acid-binding protein & FABP5 & 0.156 \\
\hline 32 & P31939 & Bifunctional purine biosynthesis protein PURH & ATIC & 0.158 \\
\hline 33 & P12277 & Creatine kinase B-type & CKB & 0.158 \\
\hline 34 & P00441 & Superoxide dismutase [Cu-Zn] & SOD1 & 0.161 \\
\hline 35 & Q8WWI1 & LIM domain only protein 7 & LMO7 & 0.163 \\
\hline 36 & P06733 & Alpha-enolase & ENO1 & 0.164 \\
\hline 37 & O75083 & WD repeat-containing protein 1 & WDR1 & 0.166 \\
\hline 38 & P10915 & Hyaluronan and proteoglycan link protein 1 & HAPLN1 & 0.167 \\
\hline 39 & O43399 & Tumour Protein D52 Like 2 & TPD52L2 & 0.168 \\
\hline 40 & P09211 & Glutathione S-transferase P & GSTP1 & 0.169 \\
\hline
\end{tabular}

$F-A M E=$ fresh human amnion extract, $C-A M E=$ cryopreserved human amnion extract

*The protein list was ranked by mean fold changes from all 3 amnion samples 
Table 4 Enriched Gene Ontology terms and KEGG pathway identified for proteins with reduced expression in C-AME (<0.5-fold) compared to F-AME

\begin{tabular}{|c|c|c|c|c|}
\hline & Enrichment scores & Biological pathways & Proteins (UniProt Accession no.) & $p$ \\
\hline \multicolumn{5}{|c|}{ (A) Enriched GO terms (DAVID) } \\
\hline 1 & 15.19 & GO:0098609 cell-cell adhesion & $\begin{array}{l}\text { P07355, P62820, Q8WUF5, P61026, P31947, P06733, } \\
\text { P04075, Q9H444, P43487, Q9C0C2, P30041, Q15056, } \\
\text { P46109, P31949, Q15907, Q99497, Q9UJU6, O60437, } \\
\text { P00338, Q92817, P31939, Q16643, P20810, Q9NYL9, } \\
\text { P0DMV9, Q16658, P63244, Q14847, Q8NC51, Q14247 }\end{array}$ & $1.3 \mathrm{E}-12^{*}$ \\
\hline 2 & 6.45 & GO:0043488 regulation of mRNA stability & $\begin{array}{l}\text { P27695, P25788, P25789, P25786, PODMV9, P20618, } \\
\text { P28070, O14818, Q92945, P60900, P49721, P04792, } \\
\text { P49720, Q8NC51, P28066 }\end{array}$ & $2 \mathrm{E}-6^{*}$ \\
\hline 3 & 6.45 & $\begin{array}{l}\text { GO:0051603 proteolysis involved in cellular } \\
\text { protein catabolic process }\end{array}$ & $\begin{array}{l}\text { P20618, P25788, P25789, P25786, P28070, O14818, } \\
\text { P07858, P60900, P49721, P49720 }\end{array}$ & $1 E-4^{*}$ \\
\hline 3 & 4.23 & GO:0006096 glycolytic process & P60174, P04406, P00558, P04075, P00338, P06733, P06744 & $0.026^{*}$ \\
\hline \multicolumn{5}{|c|}{ (B) KEGG pathways (DAVID) } \\
\hline 1 & 6.45 & hsa03050:Proteasome & $\begin{array}{l}\text { P20618, P25788, P25789, P25786, P28070, O14818, } \\
\text { P60900, P49721, P49720, P28066 }\end{array}$ & $3.6 \mathrm{E}-4^{*}$ \\
\hline 2 & 4.23 & hsa01130:Biosynthesis of antibiotics & $\begin{array}{l}\text { P40925, P60174, P04406, P37837, P06733, P00338, P04075, } \\
\text { Q03154, P06744, P31939, P11766, P54687, P29401, P14324, } \\
\text { P00558, P14550, P21399 }\end{array}$ & $0.014^{*}$ \\
\hline
\end{tabular}

$G O=$ gene ontology, $K E G G=$ kyoto encyclopedia of genes and genomes, $F-A M E=$ fresh human amnion extract, $C-A M E=c r y o p r e s e r v e d ~ h u m a n$ amnion extract, $D A V I D=$ database for annotation, visualization and integrated discovery

The biological events were ranked using enrichment scores. *Adjusted Benjamini $p<0.05$ represents statistical significance

respectively. Cells expressing ALDH3A1 and CD34 were observed in all primary cultures under wide-field confocal imaging (Fig. 4d). Cell quantification showed no significant difference in the mean percentages of ALDH3A1expressing cells (F-AME culture: $40 \pm 12 \%$; C-AME culture: $33 \pm 14 \%$ ) and CD34-expressing cells (F-AME culture: $20 \pm$ 10\%; C-AME culture: $17 \pm 11 \%$ ) (Fig. $4 \mathrm{e}-\mathrm{f}$ ). Similarly, no significant difference was observed for percentages of marker-expressing cells after cultivation with F-AME or CAME under flow cytometry (ALDH3A1-positive cells was $39 \pm 14 \%$ in F-AME and $44 \pm 28 \%$ in C-AME culture; whereas CD34-positive cells was $19 \pm 21 \%$ in F-AME and $17 \pm 14 \%$ in C-AME culture) (Fig. 5a-c).

\section{Discussion}

In this study, we have validated the ex vivo propagation of human CSKs from donor corneas using an ERI protocol. Culture media supplemented with AME from fresh or cryopreserved amnion did not alter cell morphology, viability and marker expression, although the cell proliferation rate was slightly reduced in cultures with C-AME. Hence, it is feasible to use soluble protein extracts from cryopreserved AM to propagate human CSKs for potential translational applications. We also characterized the proteomes of fresh and cryopreserved amnion tissues by iTRAQ approach and showed that 1385 proteins expressed at comparable levels in both FAME and C-AME and involved in various cellular pathways, including cell metabolism, epithelial-mesenchymal transition, focal adhesion, cell-ECM interaction, and cell stress regulation (proteasome activity, protein polyubiquitination), and complement cascades.

Development of tissue engineered human corneas remains one of the most important goals in ophthalmology today $[6,31]$. A major hurdle to the development of clinically relevant tissue constructs or cell-based therapy is the lack of a widely acceptable source of corneal stromal keratocytes (CSKs), which are crucial for maintaining corneal transparency, refractivity and mechanical strength $[32,33]$. Ex vivo culture of human CSKs is now possible with the use of AME and supplements [12, 18], but the safety concerns regarding use of human amnion, such as disease transmission and screening limitations, make this approach potentially difficult. Currently, the complete maternal screening for infectious diseases (e.g., HIV, HBV) takes 6 months post-partum [34, 35]. This necessitates cryopreserving the amnion, typically at $-80^{\circ} \mathrm{C}$, for a period of time before clinical and laboratory uses. In our current work, we have demonstrated that primary human CSKs can be propagated in culture media supplemented with extract from cryopreserved amnion (C-AME). This may overcome the potential limitation of using extracts from freshly harvested amnion (F-AME),

Keratocyte cultures supplemented with C-AME were comparable to those with F-AME, in terms of cell morphology and viability, although we noted a trend towards slower proliferation when using C-AME. Current literature has shown variable outcomes regarding the impact of cryopreservation on the growth-promoting properties of amnion extracts, depending on the biological model being used. Cooke and colleagues reported 


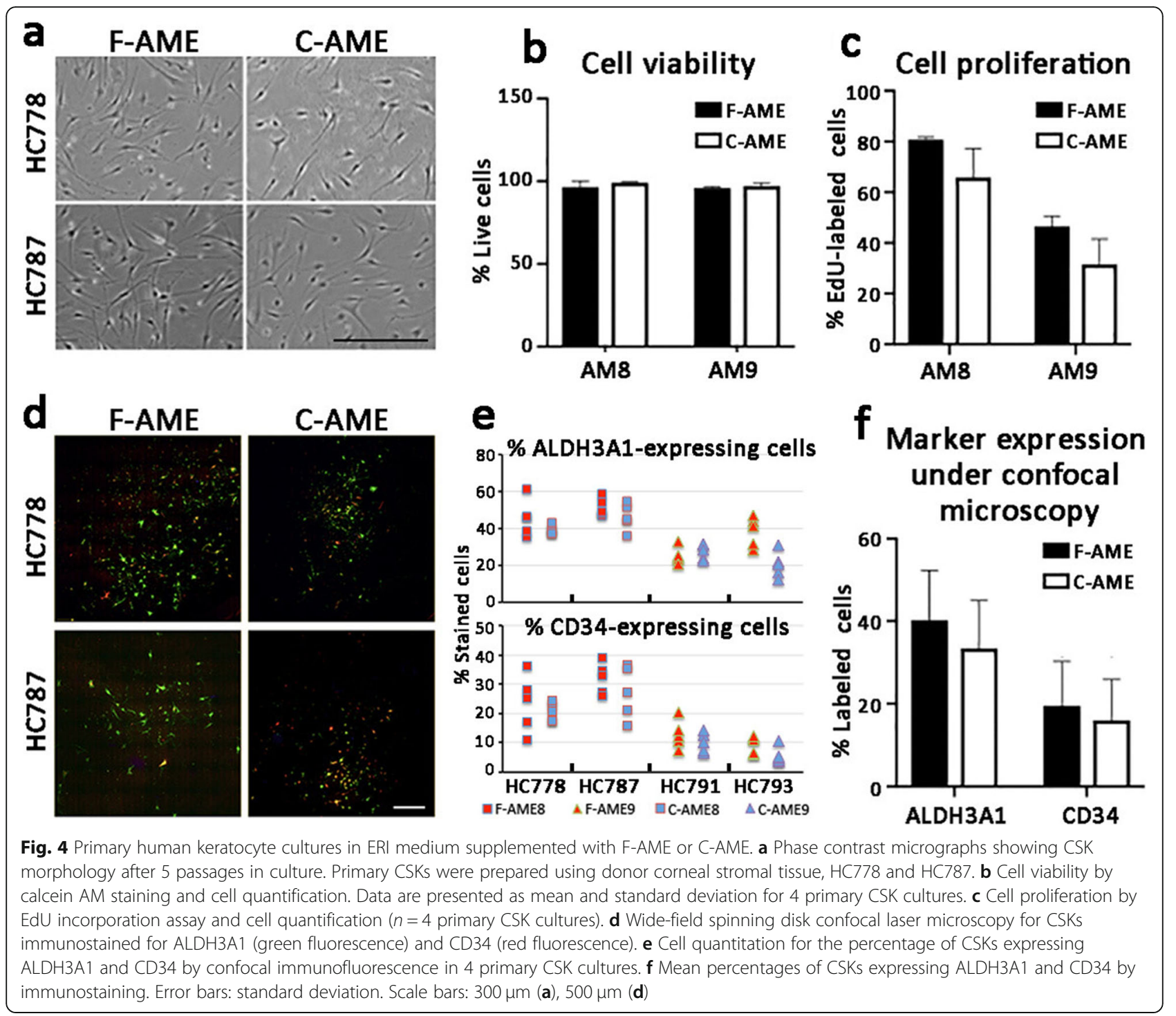

that cryopreserved amnion extracts retained antiinflammatory and anti-apoptotic properties in culturing macrophages, while dehydrated amnion lacked these activities [36]. In a mouse model of wound healing, cryopreserved and lyophilized amnion showed comparable pro- healing activity [37]. Vacuum-dried amnion was found superior to cryopreserved amnion for the expansion of corneal epithelial cells, with increased proliferation and reduced apoptosis [38]. In our work, there was a trend towards slower CSK proliferation in cultures with C-AME-supplemented media compared to that of F-AME, though the difference was not statistically significant.

Only a few studies have employed proteomic approaches to examine the protein composition of human amnion. In 2006, Park et al. reported 92 soluble and 19 membrane proteins from amnion using two-dimensional gel electrophoresis and mass spectrometry [39]. Using similar proteomic techniques to assess the protein profile of cryopreserved amnion, Hopkinson and co-workers detected 48 proteins in both the tissue and washing supernatant. They suggested some soluble proteins were released due to the preservation and tissue handling steps, resulting in inter-membrane variation, that could compromise the desired therapeutic effect after amnion transplantation [40]. In this work, we also identified 39 of these 48 proteins, of which 26 were also reduced following cryopreservation (see Supplemental Information). Enriched GO term analysis has indicated that the overall distribution of biological processes, molecular functions and cellular components for C-AME proteins were largely similar to those predicted for F-AME, including cell-cell adhesion and cell metabolism (RNA binding, actin-binding, protein biosynthesis). This indicates that there were no dramatic changes to the overall distribution of extract proteins. For the downregulated proteins 


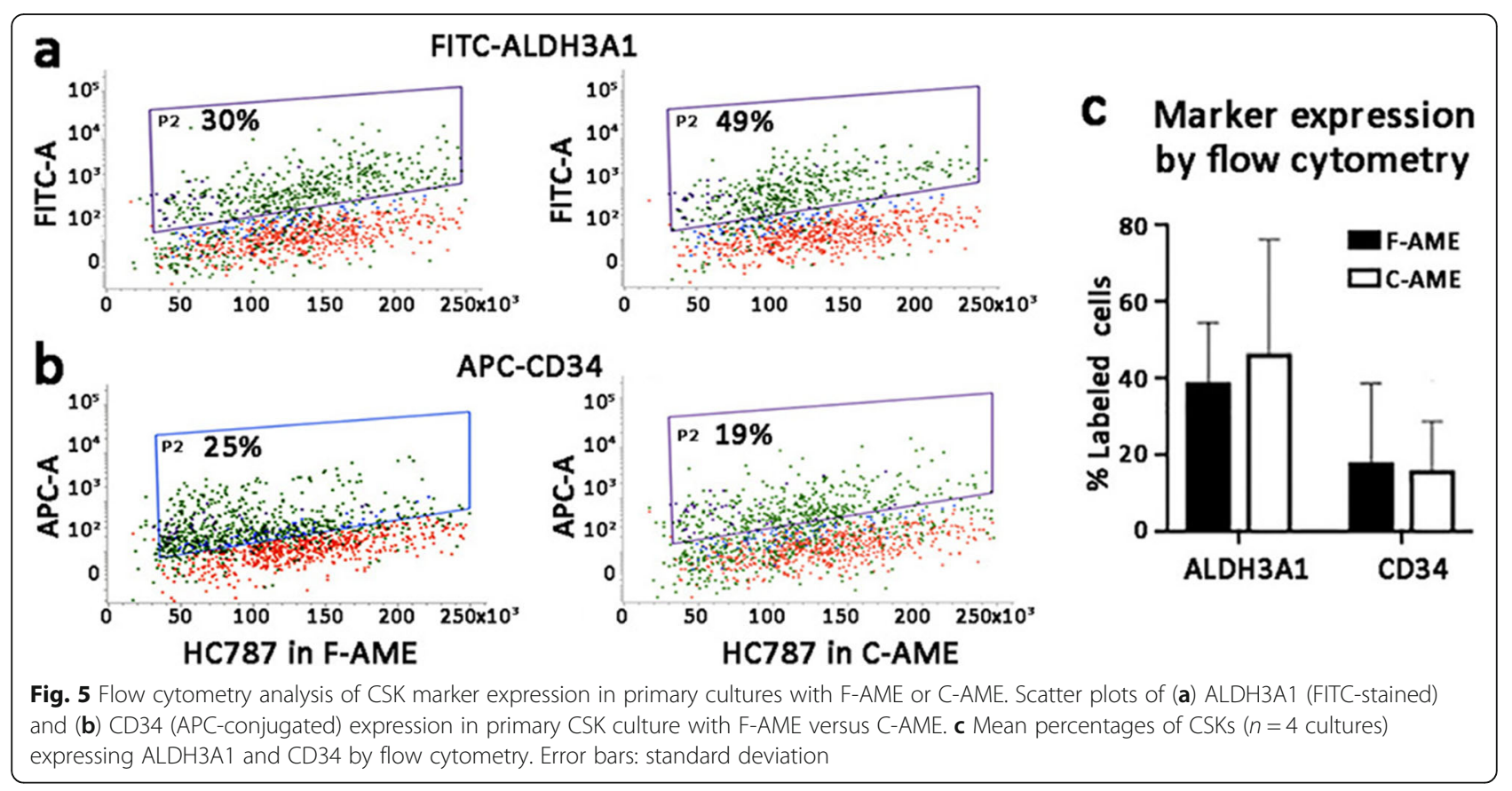

in C-AME, they were predicted to associate with several enriched GO terms, which were cell adhesion, mRNA stability and glycolytic process. This might not exert any significant effects on cell metabolism, growth and survival. The deregulated cellular functions might be compensated by proteins that remained in C-AME. Those enriched in C-AME were involved in intracellular and vesicle-mediated transport as well as cell stress response.

Fibroblast transition and growth is detrimental to CSK culture. They behave differently to bona fide CSKs (including morphologic changes, loss of CSK-specific kera$\tan$ sulphate-proteoglycans and crystallins), and their presence typically results in overgrowth with fibroblasts dominating the cell culture. The use of amnion extract in CSK culture has been associated with the suppression of $\mathrm{TGF} \beta / \mathrm{Smad}$ signalling, which downregulates $\alpha$ smooth muscle actin ( $\alpha \mathrm{SMA})$ and fibronectin expression and prevents fibroblast transformation [18, 28, 41]. Likewise, keratocan expression was preserved when mouse keratocytes were cultured inside the amnion stroma [42]. In this study, proteins present in C-AME also regulated the epithelial-mesenchymal transition, validating the effect on TGF $\beta$ signalling and fibroblast development. Other pathways included focal adhesion, cellECM interaction and receptor tyrosine kinase signalling, as well as cell stress regulation.

Despite the substantial amnion proteome identified here, the specific proteins responsible for promoting CSK growth in culture remain unknown. We identified approximately 300 secreted proteins in the amnion proteome using human secretome database analysis [43], together with previously described keratocyte growth promoters, including lumican, IGF2 and the binding proteins IGFALS and IGFBP5, being among the secreted proteins. Future work will include the identification of secreted proteins that play a role in the keratocyte growth-promoting properties of amnion extracts.

Use of AME is not limited to keratocyte culture. In a rabbit corneal damage model, topical AME has provided similar effects as that of amnion grafting [44]. It shows greater healing effect than autologous serum in treating corneal alkali injury [45]. It also dramatically reduced corneal inflammation and angiogenesis in an experimental herpes simplex keratitis model by modulating the level of proinflammatory cytokines [46]. Hence, the characterization of bioactive components present in AME could contribute to identify potentially useful AME with optimal therapeutic effects for clinical application.

Potential limitations of this work include variable protein composition of amnion extracts obtained from different donor placentas. The variable proliferation of CSKs with different amnion extracts suggests differences in amnion harvesting, storage, and potentially the physiological state of the donor mother, which may all play a role in determining the efficacy of amnion extracts for supporting CSK growth. Given the biological complexity of the amnion extract, it is also difficult to draw conclusions about the relevance of our proteomic screens, and substantial work remains to identify the growth factors or other bioactive molecules required to propagate CSKs in vitro. Another potential limitation is the use of glycerol as a cryopreservative for amnion prior to extract preparation. Previous work had indicated that even brief periods (weeks) of amnion storage in glycerol-added preservation 
medium resulted in a rapid loss of cell viability $(<30 \%$ viability) [47]. The release of proteins from dead cells in the protein extracts may have contributed to the diminished efficacy for CSK propagation compared to fresh amnion extracts. Alternative cryopreservation in the presence of dimethylsulfoxide (DMSO), a common cryoprotectant to prevent intracellular ice formation, or under freezedrying with the removal of ice through sublimation, can maintain cell viability $[48,49]$. However, our earlier report has revealed a significant loss of growth factors and ECM proteins (such as laminin and fibronectin) in freeze-dried amnion, which might produce the protein extract with reduced potential in supporting cell growth [50]. Additional experiments testing the effect of DMSO or freeze-drying would be useful to determine how the storage protocol influences the utility of amnion extracts for CSK culture.

\section{Conclusion}

In conclusion, we have demonstrated that protein extract from cryopreserved amnion was able to support the survival and proliferation of primary human CSKs. This opens new research avenues for the timely clinical application of cultured keratocytes for treating corneal stromal diseases.

\begin{abstract}
Abbreviations
ACN: Acetonitrile; ALDH: Aldehyde dehydrogenase; AME: Amnion extract; BSA: Bovine serum albumin; C-AME: Cryopreserved amnion extract; CSK: Corneal stromal keratocyte; DAPI: 4',6-diamidino-2-phenylindole; DAVID: Database for annotation, visualization and integrated discovery; DMEM: Dulbecco's modified Eagle medium; ECM: Extracellular matrix; ELISA: Enzyme-linked immunosorbent assay; ESI: Electrospray ionization; FAME: Fresh amnion extract; FBS: Fetal bovine serum; FDR: False discovery rate; GO: Gene ontology; IDA: Information-dependent acquisition; IGF1: Insulin-like growth factor 1; iTRAQ: Isobaric tagging for relative and absolute quantitation; KEGG: Kyoto encyclopedia of genes and genomes; MS: Mass spectrometry; NGS: Normal goat serum; PBS: Phosphate buffered saline; r.p.m.: Round-per-minute; ROCK: Rho-associated coiled-coil containing protein kinase; SD: Standard deviation; SDS-PAGE: Sodium dodecylsulfatepolyacrylamide gel electrophoresis; TGF: Transforming growth factor; TIMP1: Tissue inhibitor of metalloproteinase 1
\end{abstract}

\section{Acknowledgements}

We thank the Lion Eye Institute for Transplant and Research (Tampa, FL, US) for their assistance with procurement of research grade donor corneas. We also thank the Singapore Eye Bank, Singapore National Eye Centre, for the help in amnion collection (consent taking and tissue processing). We acknowledge SingHealth Advanced Bioimaging Core Facilities for confocal microscopy.

\section{Authors' contributions}

GY and JM designed experiments; BF, GY and JM wrote and approved the manuscript; BF, NZ, MF, FB, and LZ performed experiments and data acquisition; JM and HT provided samples; HC obtained patient consent and ethics approval; BF, NZ and GY interpreted data; all authors reviewed the manuscript. All authors read and approved the final manuscript.

\section{Funding}

Singapore National Eye Centre HREF 0618-2 and Singapore National Research Foundation under Clinician Scientist Award - Senior Investigator Category (JRNMRR163801), National Medical Research Council, Ministry of Health, Singapore.

\section{Availability of data and materials}

All data are included in the text and supplemental information.

\section{Ethics approval and consent to participate}

Human placenta collection was approved by the institutional review board (2015/2607, SingHealth, Singapore) and written consent obtained from mothers. Research-grade donor corneal tissues were procured from Lions Eye Institute for Transplant and Research Inc. (Tampa, FL, US) following institutional review board approval, in accordance with approved guidelines. Consent was taken at the time of retrieval by the next of kin, for use in research.

\section{Consent for publication}

Not applicable.

\section{Competing interests}

The authors declare that they have no competing interests.

\section{Author details}

${ }^{1}$ Tissue Engineering and Stem Cell Group, Singapore Eye Research Institute, 20 College Road, The Academia, Discovery Tower Level 6, Singapore 169856, Singapore. ${ }^{2}$ Singapore National Eye Centre, Singapore, Singapore. ${ }^{3}$ Department of Ophthalmology, RWTH Aachen University, Aachen, Germany. ${ }^{4}$ Eye-Academic Clinical Programme, Duke-NUS Graduate Medical School, Singapore, Singapore. ${ }^{5}$ Proteomics Platform, Singapore Eye Research Institute, Singapore, Singapore. ${ }^{6}$ Federal University of São Paulo, Sao Paulo, Brazil. ${ }^{7}$ Singapore Eye Bank, Singapore, Singapore. ${ }^{8}$ Department of Obstetrics and Gynaecology, Singapore General Hospital, Singapore, Singapore.

Received: 24 May 2019 Accepted: 20 September 2019

Published online: 12 October 2019

\section{References}

1. Meek KM, Knupp C. Corneal structure and transparency. Prog Retin Eye Res. 2015;49:1-16.

2. Robaei D, Watson S. Corneal blindness: a global problem. Clin Exp Ophthalmol. 2014;42(3):213-4.

3. Mathews PM, Lindsley K, Aldave AJ, Akpek EK. Etiology of global corneal blindness and current practices of corneal transplantation: a focused review. Cornea. 2018;37(9):1198-203.

4. Mohamed-Noriega K, Angunawela RI, Tan D, Mehta JS. Corneal transplantation: changing techniques. Transplantation. 2011;92(7):e31-2.

5. de Sanctis U, Alovisi C, Bauchiero L, Caramello G, Girotto G, Panico C, et al. Changing trends in corneal graft surgery: a ten-year review. Int J Ophthalmol. 2016;9(1):48-52.

6. Gain P, Jullienne R, He Z, Aldossary M, Acquart S, Cognasse F, et al. Global survey of corneal transplantation and eye banking. JAMA Ophthalmol. 2016;134(2):167-73.

7. Ghezzi CE, Rnjak-Kovacina J, Kaplan DL. Corneal tissue engineering: recent advances and future perspectives. Tissue Eng Part B Rev. 2015;21(3):278-87.

8. Fuest M, Yam GH, Peh GS, Mehta JS. Advances in corneal cell therapy. Regen Med. 2016;11(6):601-15.

9. Parekh M, Ferrari S, Sheridan C, Kaye S, Ahmad S. Concise review: an update on the culture of human corneal endothelial cells for transplantation. Stem Cells Transl Med. 2016;5(2):258-64.

10. Gomes ME, Rodrigues MT, Domingues RMA, Reis RL. Tissue engineering and regenerative medicine: new trends and directions - a year in review. Tissue Eng Part B Rev. 2017;23(3):211-24.

11. Stern JH, Tian Y, Funderburgh J, Pellegrini G, Zhang K, Goldberg JL, et al. Regenerating eye tissues to preserve and restore vision. Cell Stem Cell. 2018;22(6):834-49.

12. Yam GH, Fuest M, Yusoff NZ, Goh TW, Bandeira F, Setiawan M, et al. Safety and feasibility of intrastromal injection of cultivated human corneal stromal keratocytes as cell-based therapy for corneal opacities. Invest Ophthalmol Vis Sci. 2018:59(8):3340-54.

13. Sidney LE, Hopkinson A. Corneal keratocyte transition to mesenchymal stem cell phenotype and reversal using serum-free medium supplemented with fibroblast growth factor-2, transforming growth factor- $\beta 3$ and retinoic acid. J Tissue Eng Regen Med. 2018;12(1):e203-15.

14. Che X, Wu H, Jia C, Sun H, Ou S, Wang J, et al. A novel tissue-engineered corneal stromal equivalent based on amniotic membrane and keratocytes. Invest Ophthalmol Vis Sci. 2019;60(2):517-27. 
15. Fini ME. Keratocyte and fibroblast phenotypes in the repairing cornea. Prog Retin Eye Res. 1999;18(4):529-51.

16. Funderburgh $J$, Mann MM, Funderburgh ML. Keratocyte phenotype mediates proteoglycan structure: a role for fibroblasts in corneal fibrosis. J Biol Chem. 2003;278(46):45629-37.

17. Du Y, Carlson EC, Funderburgh ML, Birk DE, Pearlman E, Guo N, et al. Stem cell therapy restores transparency to defective murine corneas. Stem Cells. 2009;27(7):1635-42.

18. Yam GH, Yusoff NZ, Kadaba A, Tian D, Htoon HM, Beuerman RW, et al. Ex vivo propagation of human corneal stromal "activated keratocytes" for tissue engineering. Cell Transplant. 2015;24(9):1845-61.

19. Dua HS, Gomes JA, King JA, Maharajan VS. The amniotic membrane in ophthalmology. Surv Ophthalmol. 2004;49(1):51-77.

20. Tseng SC, Espana EM, Kawakita T, Di Pascuale MA, Li W, He H, et al. How does amniotic membrane work? Ocul Surf. 2004;2(3):177-87.

21. Maharajan VS, Shanmuganathan V, Currie A, Hopkinson A, Powell-Richards A, Dua HS. Amniotic membrane transplantation for ocular surface reconstruction: indications and outcomes. Clin Exp Ophthalmol. 2007;35(2): $140-7$.

22. Castro-Combs J, Noguera G, Cano M, Yew M, Gehlbach PL, Palmer J, et al. Corneal wound healing is modulated by topical application of amniotic fluid in an ex vivo organ culture model. Exp Eye Res. 2008;87(1):56-63.

23. Rauz S, Saw VP. Serum eye drops, amniotic membrane and limbal epithelial stem cells--tools in the treatment of ocular surface disease. Cell Tissue Bank. 2010;11(1):13-27.

24. Go YY, Kim SE, Cho GJ, Chae SW, Song JJ. Differential effects of amnion and chorion membrane extracts on osteoblast-like cells due to the different growth factor composition of the extracts. PLoS One. 2017;12:e0182716.

25. Yadav MK, Go YY, Kim SH, Chae SW, Song JJ. Antimicrobial and antibiofilm effects of human amniotic/chorionic membrane extract on Streptococcus pneumoniae. Front Microbiol. 2017;8:1948.

26. Khorramirouz R, Kamell SM, Fendereski K, Daryabari SS, Kajbafzadeh AM. Evaluating the efficacy of tissue-engineered human amniotic membrane in the treatment of myocardial infarction. Regen Med. 2019;14(2):113-26.

27. Kuk N, Hodge A, Sun Y, Correia J, Alhomrani M, Samuel C, et al. Human amnion epithelial cells and their soluble factors reduce liver fibrosis in murine non-alcoholic steatohepatitis. J Gastroenterol Hepatol. 2019;34(8): 1441-9.

28. Tseng SC, Li DQ, Ma X. Suppression of transforming growth factor-beta isoforms, TGF-beta receptor type II, and myofibroblast differentiation in cultured human corneal and limbal fibroblasts by amniotic membrane matrix. J Cell Physiol. 1999;179(3):325-35.

29. Espana EM, He H, Kawakita T, Di Pascuale MA, Raju VK, Liu CY, et al. Human keratocytes cultured on amniotic membrane stroma preserve morphology and express keratocan. Invest Ophthalmol Vis Sci. 2003;44(12):5136-41.

30. Mi H, Huang X, Muruganujan A, Tang H, Mills C, Kang D, et al. PANTHER version 11: expanded annotation data from Gene Ontology and Reactome pathways, and data analysis tool enhancements. Nucleic Acids Res. 2017; 45(D1):D183-9.

31. Duarte Campos DF, Rohde M, Ross M, Anvari P, Blaesar A, Vogt M, et al. Corneal bioprinting utilizing collagen-based bioinks and primary human keratocytes. J Biomed Mater Res A. 2019;107(9):1945-53.

32. Nishida K. Tissue engineering of the cornea. Cornea. 2003;22(7 Suppl):S28-34.

33. Larouche D, Paquet C, Fradette J, Carrier P, Auger FA, Germain L. Regeneration of skin and cornea by tissue engineering. Methods Mol Biol. 2009:482:233-56.

34. Malhotra C, Jain AK. Human amniotic membrane transplantation: different modalities of its use in ophthalmology. World J Transplant. 2014;4(2):111-21.

35. Meissner-Roloff M, Gaggia L, Vermeulen M, Mazanderani AFH, du Plessis NM, Steel HC, et al. Strategies for screening cord blood for a public cord blood bank in high HIV prevalence regions. Glob Health Epidemiol Genom. 2018;3:e9.

36. Cooke M, Tan EK, Mandrycky C, He H, O'Connell J, Tseng SC. Comparison of cryopreserved amniotic membrane and umbilical cord tissue with dehydrated amniotic membrane/chorion tissue. J Wound Care. 2014;23(10): 465-74, 476

37. Dhall S, Sathyamoorthy M, Kuang JQ, Hoffman T, Moorman M, Lerch A, et al. Properties of viable lyopreserved amnion are equivalent to viable cryopreserved amnion with the convenience of ambient storage. PLoS One. 2018;13(10):e0204060.
38. Allen CL, Clare G, Stewart EA, Branch MJ, Mclntosh OD, Dadhwal M, et al. Augmented dried versus cryopreserved amniotic membrane as an ocular surface dressing. PLoS One. 2013;8(10):e78441.

39. Park SJ, Yoon WG, Song JS, Jung HS, Kim CJ, Oh SY, et al. Proteome analysis of human amnion and amniotic fluid by two-dimensional electrophoresis and matrix-assisted laser desorption/ionization time-of-flight mass spectrometry. Proteomics. 2006;6(1):349-63.

40. Hopkinson A, Mclntosh RS, Sathyamoorthy V, Tighe PJ, Dua HS. Proteomic analysis of amniotic membrane prepared for human transplantation: characterization of proteins and clinical implications. J Proteome Res. 2006; 5(9):2226-35.

41. Lee SB, Li DQ, Tan DT, Meller DC, Tseng SC. Suppression of TGF-beta signalling in both normal conjunctival fibroblasts and pterygial body fibroblasts by amniotic membrane. Curr Eye Res. 2000;20(4):325-34.

42. Kawakita T, Espana EM, He H, Hornia A, Yeh LK, Ouyang J, et al. Keratocan expression of murine keratocytes is maintained on amniotic membrane by down-regulating transforming growth factor- $\beta$ signalling. J Biol Chem. 2005; 280(29):27085-92

43. Chen Y, Zhang Y, Yin Y, Gao G, Li S, Jiang Y, et al. SPD--a web-based secreted protein database. Nucleic Acids Res. 2005;33(Database issue):D169-73.

44. Guo Q, Hao J, Yang W, Guan L, Ouyang S, Wang J. A comparison of the effectiveness between amniotic membrane homogenate and transplanted amniotic membrane in healing corneal damage in a rabbit model. Acta Ophthalmol. 2011;89(4):e315-9.

45. Shahriari HA, Tokhmehchi F, Reza M, Hashemi NF. Comparison of the effect of amniotic membrane suspension and autologous serum on alkaline corneal epithelial wound healing in the rabbit model. Cornea. 2008;27(10): 1148-50.

46. Heiligenhaus A, Li H, Hernandez Galindo EE, Koch JM, Steuhi KP, Meller D. Management of acute ulcerative and necrotising herpes simplex and zoster keratitis with amniotic membrane transplantation. Br J Ophthalmol. 2003; 87(10):1215-9.

47. Wagner $M$, Walter $\mathrm{P}$, Salla $\mathrm{S}$, Johnen $\mathrm{S}$, Plange $\mathrm{N}$, Rütten $\mathrm{S}$, et al. Cryopreservation of amniotic membrane with and without glycerol additive. Graefes Arch Clin Exp Ophthalmol. 2018;256(6):1117-26.

48. Nakamura T, Yoshitani M, Rigby H, Fullwood NJ, Ito W, Inatomi T, et al. Sterilized, freeze-dried amniotic membrane: a useful substrate for ocular surface reconstruction. Invest Ophthalmol Vis Sci. 2004;45(1):93-9.

49. Hettiarachchi D, Dissanayake VH, Goonasekera HW. Optimizing amniotic membrane tissue banking protocols for ophthalmic use. Cell Tissue Bank. 2016;17(3):387-97.

50. Lim LS, Poh RW, Riau AK, Beuerman RW, Tan D, Mehta JS. Biological and ultrastructural properties of acelagraft, a freeze-dried $\gamma$-irradiated human amniotic membrane. Arch Ophthalmol. 2010;128(10):1303-10.

Ready to submit your research? Choose BMC and benefit from:

- fast, convenient online submission

- thorough peer review by experienced researchers in your field

- rapid publication on acceptance

- support for research data, including large and complex data types

- gold Open Access which fosters wider collaboration and increased citations

- maximum visibility for your research: over $100 \mathrm{M}$ website views per year

At $\mathrm{BMC}$, research is always in progress.

Learn more biomedcentral.com/submission 